\title{
Peranan Media Sosial Facebook Dalam Manajemen Publikasi Informasi Fakultas Tarbiyah Dan Ilmu Keguruan Iain Kendari
}

\author{
Nur Alim ${ }^{1)}$; Titin Retnawati²; Syamsuddin ${ }^{3}$ \\ Fakultas Tarbiyah dan Ilmu Keguruan Institut Agama Islam Negeri Kendari \\ Corresponding Author: nuralimbasri@gmail.com
}

\begin{abstract}
This study discusses the role of social media in the management of information publications Tarbiyah and Teacher Training Faculty of IAIN Kendari. The results of the study showed that the management of information publication at the Tarbiyah and Teacher Training Faculty of IAIN Kendari was divided into four stages. First, the planning stage, which includes analysis of information to be published, namely academic, student or general information, related parties involved in the publication, namely the leadership of the Tarbiyah Faculty and administrative staff. As well as media publications to be used, namely Facebook social media and print media. Second, the organizing stage, namely the administration of the Tarbiyah Faculty has five administrative staff in charge of organizing information publications. Third, the implementation stage, this information publication was carried out by administrative staff as well as the head of the Tarbiyah Faculty administration section through the use of print media and Facebook. The last stage is supervision, where faculty leaders are involved in supervising the publication of that information. The role of Facebook in the management of information publications at the Tarbiyah and Teacher Training Faculty of IAIN Kendari consists of three roles, namely information optimization, ease of publication and access to information, and has interesting features in information publication.
\end{abstract}

Keywords: facebook; information publishing management; social media

Abstrak
Penelitian ini membahas peranan mediasosial facebook dalam manajemen publikasi
informasiFakultas Tarbiyah dan Ilmu KeguruanIAIN Kendari. Hasil penelitian menunjukkan
bahwa manajemen publikasi informasi Fakultas Tarbiyah dan Ilmu Keguruan IAIN Kendari
terbagi menjadi empat tahap. Pertama, tahapperencanaan, yangmeliputi analisis informasi
yang akan dipublikasikan, yakni informasi akademik, kemahasiswaan atau umum, pihak-pihak
terkait yang terlibat dalam publikasi, yaitu pimpinan Fakultas Tarbiyahserta staf administrasi.
Serta media publikasi yang akan digunakan, yaitu media sosial facebook dan media cetak.
Kedua, Tahap pengorganisasian, yakni tata usaha Fakultas Tarbiyah memiliki lima orang staf
administrasi yang bertugas menyelenggarakan publikasi informasi. Ketiga, tahap Pelaksanaan,
publikasi informasi ini dilakukan oleh staf administrasi juga kepala bagian tata usaha Fakultas
Tarbiyah melalui penggunaan media cetak dan media sosial facebook. Tahap terakhir yakni
pengawasan, dimana pimpinan fakultas ikut terlibat dalam pengawasan publikasi informasi itu.
Peranan media sosial facebook dalam manajemen publikasi informasi di Fakultas


Tarbiyah dan Ilmu Keguruan IAIN Kendari, terdiri atas tiga peranan, yaitu optimalisasi informasi, kemudahan publikasi dan akses informasi, serta memiliki fitur-fitur menarik dalam publikasi informasi.

\section{Kata kunci: facebook; manajemen publikasi informasi; media sosial}

\section{A. Pendahuluan}

Perkembangan dunia maya kian hari kian pesat. Dimulai dari hanya pemakaian website dan surel, kemudian makin berkembang dengan munculnya berbagai media sosial di dunia maya, seperti blog pribadi, kemudian bermunculan berbagai media social lain dengan berbagai macam tawaran fitur yang menarik. Situs-situs jejaring social yang banyak diminati oleh masyarakat diantaranya adalah Facebook, LinkedIn, Pinterest, Instagram, Twitter. ${ }^{1}$ Hal ini tentu saja juga terjadi di Indonesia. ${ }^{2}$ Hasil pengamatan seorang "Facebooker", menunjukkan bahwa media sosial facebook ini tidak hanya untuk keperluan komunikasi semata atau untuk update status, tetapi juga telah banyak difungsikan untuk tujuan politik, bisnis dan bahkan telah terintegrasi kedalam sistem pendidikan. ${ }^{3}$

Media sosial adalah media untuk interaksi sosial, dengan menggunakan teknik komunikasi yang sangat mudah dan scalable. ${ }^{4}$ Boyd memaparkan bahwa media sosial sebagai kumpulan perangkat lunak yang memungkinkan individu maupun komunitas untuk berkumpul, berbagi, berkomunikasi, dan dalam kasus tertentu saling berkolaborasi atau bermain. Media sosial memiliki kekuatan pada user-generated content (UGC) atau interaksi konten yang dihasilkan oleh pengguna, bukan oleh editor sebagaimana di instansi media massa. ${ }^{5}$

Fakultas Tarbiyah dan Ilmu keguruan merupakan salah satu fakultas di IAIN Kendari yang memiliki banyak peminat dibandingkan dengan fakultas lainnya. Jumlah mahasiswa fakultas ini kurang lebih dua ribu orang. ${ }^{6}$ Sehingga dalam penyebaran informasi, pihak penyebar informasi mengalami kesusahan. Olehnya itu setiap informasi terkait dengan akademik dan kemahasiswaan yang akan disebarkan kepada

${ }^{1}$ Ellison M Duggan, N. B., Lampe, C., Lenhart, A., \& Madden, M. Social Media Site Usage 2014. http://www. pewinternet. org/2015/01/09/socialmedia-update-2014/, 2015 Diunduh 18 Agustus 2017.

2 Yeni Imaniar Hamzah, "Potensi Media Sosial Sebagai Sarana Promosi Interaktif Bagi Pariwisata Indonesia”, Jurnal JKL, Vol. 8 No. 3 Tahun 2013, h. 1

${ }^{3}$ Marham Jupri Hadi, "Pemanfaatan Media Sosial Facebook Sebagai Media Peningkatan Kemampuan Menulis Mahasiswa", Jurnal Linguistik, Sastra, dan Pendidikan (JURNALISTRENDI) Vol.1 No.1 Tahun 2016, h. 1.

${ }^{4}$ Hasan Basri, "Peran Media Sosial Twitter Dalam Interaksi Sosial Pelajar Sekolah Menengah Pertama Di Kota Pekanbaru (Studi Kasus Pelajar Smpn 1 Kota Pekanbaru)”, Jom FISIP Vol. 4 No. 2 (Oktober 2017): 1-15

${ }^{5}$ Riya Widayanti, "Pemanfaatan Media Sosial Untuk Penyebaran Informasi Kegiatan Sekolah Menengah Kejuruan Pasundan Tangerang”, Jurnal: Abdimas, Vol. 1 No. 2 (Maret 2015). h. 84

${ }^{6}$ Data Sistem Informasi Akademik Fakultas Tarbiyah IAIN Kendari, tahun 2018. 
mahasiswa, oleh kepala Bagian Tata Usaha, Amari, S.Ag., M. AP memiliki inisiatif untuk memanfaatkan media sosial.

Salah satu media sosial yang digunakan di Fakultas Tarbiyah dan Ilmu Keguruan adalah Facebook. Facebook adalah sebuah situs web jejaring sosial/networking yang memungkinkan penggunanya dapat berinteraksi sosial dan berbagi informasi diseluruh dunia. Facebook diluncurkan pada 4 Februari 2004 oleh Mark Zuckerberg seorang mahasiswa Harvard kelahiran 14 Mei 1984 dan mantan murid Ardsley High School. ${ }^{7}$

Akun facebook resmi yang dikelolah oleh Kepala Bagian Tata Usaha FATIK bernama TU Fatik IAIN Kendari sejak tahun 2017 lalu. Kebijakan ini diambil oleh Fakultas tarbiyah dan Ilmu Keguruan IAIN Kendari oleh karena banyaknya mahasiswa di fakultas ini bahkan yang terbanyak dibandigkan dengan fakultas lain di IAIN Kendari. Untuk lebih membuat segala bentuk publikasi yang terkait dengan informasi kegiatan akademik, maka dipandang perlu untuk membuat akun facebook untuk memudahkan komunikasi antara fakultas dengan para mahasiswa, termasuk alumni. Media facebook dipilih oleh karena media ini dianggap sebagai media yang paling abnyak digunakan oleh mahasiswa Fakultas Tarbiyah. Rilis surat kabar menyebutkan bahwa Indonesia adalah negara pengguna facebook terbanyak keempat di dunia. Bahkan pengguna facebook ini pada tahun 2017 mencapai lebih dari dua milyar. ${ }^{8}$ Penggunaan media social ini juga disesuaikan dengan minat dan kekerapan mahasiswa mengakses informasi lebih cepat dengan menggunakan media social diabandingkan dengan cara manual atau lisan. Melalui akun ini, setiap informasi rangkaian kegiatan akademik dan kemahasiswaan dipublikasikan. Penyebaran informasi lewat media sosial facebook ini, mendapat respon positif dari mahasiswa Fakultas Tarbiyah terlepas dari respon terhadap informasi yang dipublikasikan. Ditambah lagi dalam penyebaran infomasi, senantiasa menerapkan fungsi manajemen. Olehnya itu informasi yang dipublikasikan tersebut bisa terdistribusikan dengan secara sistematis dan lebih optimal. Sehingga mahasiswa merasa terbantu dengan adanya media sosial facebook ini dalam mendapatkan informasi jika dibandingkan dengan peyebaran informasi dengan menggunakan sistem hardfile, yakni lewat selembaran kertas yang ditempel di papan informasi.

Penelitian-penelitian yang pernah dilakukan terkait dengan penelitian ini diantaranya adalah penelitan Hasnah tentang efektivitas pemanfaatan internet sebagai sarana belajar di MTs.N Unaaha Kabupaten Konawe. Penelitian tersebut menjelaskan bahwa pemanfaatan media sosial (internet) di madrasah tersebut mempermudah dan mempercepat siswa dalam mencari sumber informasi dan pembelajaran serta berfungsi juga sebagai media pembelajaran dalam menghilangkan kendala tempat, karena siswa

${ }^{7}$ Asmaya, Fela. Pengaruh Penggunaan Media Sosial Facebook Terhadap Perilaku Prososial Remaja Di Kenagarian Kota Bangun. Jurnal: Jom FISIP Volume 2 No. 2 (Oktober 2015), h. 3.

${ }^{8}$ https://tekno.kompas.com/read/2018/03/02/08181617/indonesia-pengguna-facebookterbanyak-ke-4-di-dunia. Diakses tanggal 12 Oktober 2018; Lihat pula https://tech.koropak.co.id/1479/tahun-2018-facebook-masih-mendominasi-media-sosial. Diakses tanggal 12 Oktober 2018. 
dapat mempercepat dan mempermudah dalam mengakses materi pelajaran serta siswa dapat belajar walau pengajar berada ditempat yang berbeda. Sistem ini secara tidak langsung membantu penggunaan waktu secara efektif dan meringankan beban guru yang bersangkutan. Penelitian lain dilakukan oleh Riya Widayanti tentang pemanfaatan media sosial untuk penyebaran informasi kegiatan Sekolah Menengah Kejuruan Pasundan Tangerang. Hasil penelitian ini menemukan bahwa media sosial sangat mudah digunakan dibandingkan dengan pengelolaan web yang membutuhkan tenaga administrator. Penyebaran informasi pun lebih efektif sehingga segala informasi yang berkaitan dengan akademik mampu diketahui oleh kalangan stakeholder sekolah, yakni guru, siswa, orang tua siswa dan pemerhati lembaga tersebut. Ita Fachriyah \& LM. Tajidun melakukan penelitian tentang implementasi SMS Gateway dan Papan Pengumuman Digital Penyebaran Informasi Kegiatan Akademik di Jurusan Teknik Informatika Universitas Halu Oleo. Hasil penelitian ini menunjukkan bahwa penyebaran informasi dengan menggunakan Papan Pengumuman Digital dan SMS Gateway atau Publikasi Informasi melalui sistem internet lebih optimal. Penelitian lain dilakukan oleh Untung Rahardja, Khanna Tiara, Lia Suci Wulandari tentang penerapan Web Alumni sebagai penunjang media informasi di perguruan tinggi Raharja yang menemukan bahwa keberadaan web pengolahan data alumni sistem informasi dapat diperoleh dengan baik sesuai dengan kebutuhan alumni dan dapat diakses dengan baik pula ${ }^{9}$. Berbeda dengan penelitian-penelitian tersebut, penelitian ini dilakukan di Fakultas Tarbiyah dan Ilmu Keguruan IAIN Kendari yang difokuskan pada pemanfaatan media social facebook dalam menyebarkan informasi akademik kepada para mahasiswa di lingkup Fakultas Tarbiyah dan Ilmu Keguruan IAIN Kendari. Penelitian ini hendak menguji apakah penggunaan media sosial facebook di Fakultas Tarbiyah dan Ilmu Keguruan IAIN Kendari dapat termanfaatkan dengan baik oleh para penggunanya (mahasiswa) dan apakah media tersebut cukup efektif dalam proses penyebaran dan penyampaian informasi sebagaimana yang dikehendaki oleh pimpinan fakultas.

Metode penelitian yang digunakan adalah metode deskriptif dengan menggunakan pendekatan kualitatif. Peneliti melakukan penelitian selama tiga bulan masa penelitian pada bulan Februari-April untuk benar-benar bisa mendapatkan informasi maupun data yang sesuai dengan keadaan di Fakultas Tarbiyah dan Ilmu Keguruan IAIN Kendari. Peneliti menjadi key informan (informan kunci) yang mengetahui segala sesuatu mengenai hal yang diteliti oleh peneliti, selain itu peneliti menggunakan pihak-pihak lain untuk mendapatkan data yag dibutuhkan oleh peneliti melalui kepala bagian tata usaha Fakultas Tarbiyah dan Ilmu Keguruan, staf administrasi, serta mahasiswa. Peneliti menggunakan pendekatan POAC (planning, organizing, acting, controlling) untuk melihat proses penyebaran dan pendistribusian berita serta informasi melalui media sosial facebook kepada pengguna dalam hal ini

${ }^{9}$ Untung Rahardja, Khanna Tiara, Lia Suci Wulandari, "Penerapan Web Alumni Sebagai Penunjang Media Informasi Pada Perguruan Tinggi Raharja", Makalah pada Seminar Nasional Teknologi Informasi dan Multimedia 2016 STMIK AMIKOM Yogyakarta, 6-7 Februari 2016 
adlah mahasiswa. Teknik yang digunakan untuk memilih subjek penelitian, yakni Purposive Sampling dan Snowball Sampling. Teknik pengumpulan data melalui wawancara, observasi dan dokumentasi.

\section{B. Manajemen Publikasi Informasi Fakultas Tarbiyah dan Ilmu Keguruan IAIN Kendari}

Perecanaan adalah pemilihan kegiatan dan memutuskan apa saja yang harus dilakukan, kapan, bagaimana serta oleh siapa kegiatan tersebut dilakukan. Fakultas Tarbiyah dan Ilmu Keguruan IAIN Kendari menerapkan fungsi manajemen dalam publikasi informasi, dimulai dari fungsi perencanaan, pengorganisasisian, pelaksanaan, dan pengawasan publikasi informasi.

a) Perencanaan Publikasi Informasi

Perencanaan publikasi informasi Fakultas Tarbiyah dan Ilmu Keguruan IAIN Kendari sebagaimana yang dikemukakan oleh Kepala bagian tata usaha Fakultas Tarbiyah dan Ilmu Keguruan, menuturkan bahwa sebelum melakukan publikasi informasi, sebagaimana dituturkan berikut: ${ }^{10}$

Dalam publikasi informasi, ada tiga macam informasi yang dipublikasikan, yakni informasi akademik, kemahasiswaan dan informasi umum. Jadi, hal yang diperhatikan dalam perencanaan publikasi yakni analisis jenis informasi yang disebarkan tersebut. Kemudian informasi yang akan disebarkan itu disusun secara runtut, terstruktur dan tidak berbelit belit sehingga maksud dan tujuan informasi itu mudah kami pahami. Bahasa yang digunakan pun dengan menggunakan bahasa yang baku dan bahasa sehari-hari yang digunakan.

Maulana Akbar (Staf Administrasi) ${ }^{11}$, dalam wawancaranya pun menuturkan bahwa:

Informasi yang dipublikasikan merupakan hasil dari musyawarah dari pimpinan fakultas. Misalnya informasi akademik terkait Yudisium, PPL (praktek pengalaman Lapangan), pihak yang terlibat adalah dekan Fakultas Tarbiyah, wakil dekan I, II, III, dan masing-masing ketua prodi. Kemudian informasi tersebut secara teknis kami buat dan dipublikasikan kepada mahasiswa melalui media facebook maupun media manual.

Berdasarkan wawancara dengan informan dan observasi penulis, pada tahap ini kegiatan yang dilakukan adalah analisis informasi yang akan dipublikasikan. Adapun informasinya yakni terkait dengan informasi akademik, kemahasiswaan, dan informasi umum. Informasi akademik adalah segala informasi yang berkaitan dengan mahasiswa dari masa perekrutannya sampai menjadi output. Misalnya, informasi peenerimaan mahasiswa, penawaran, PPL/magang, KKN, Tahsinul Qiroah, yudisium dan lain sebagainya. Informasi kemahasiswaan adalah segala informasi yang lebih merujuk

\footnotetext{
${ }^{10}$ Amari, wawancara, 5 Maret 2018.

${ }^{11}$ Maulana Akbar, wawancara, 5 Maret 2018.
} 
kepada sosialisasi terhadap mahasiswa, misalnya informasi pemilihan DEMA (Dewan Mahasiswa) dan jajarannya. Serta informasi umum adalah semua informasi keseluruhan yang menyangkut mahasiswa, maupun pimpinan. Misalnya keterlibatan pimpinanan dalam suatu kegiatan pengabdian masyarakat.

Selanjutnya pihak-pihak yang terkait dalam publikasi informasi, yakni pimpinan Fakultas Tarbiyah, masing-masing ketua prodi, dan kabag tata usaha serta staf administrasi Fakultas Tarbiyah. Media publikasi yang digunakan, serta analisis media yang digunakan untuk publikasi, ada dua yaitu media sosial facebook dan media cetak. Hal ini dilakukan agar informasi yang dipublikasikan itu tersusun secara runtut, terstruktur dan tidak berbelit belit sehingga maksud dan tujuan informasi itu mudah dipahami.

b) Pengorganisasian Publikasi Informasi

Pengorganisasi berasal dari kata "organizing" berasal dari Bahasa Yunuani dengan akar katanya "organon" yang berarti alat, yaitu proses pengelompokan kegiatan-kegiatan untuk mencapai tujuan tertentu yang dilakukan oleh seorang manajer dengan menugaskan orang-orang tertentu sesuai tugasnya. ${ }^{12}$ Pengorganisasian dengan demikian diartikan sebagai kegiatan membagi pekerjaan kepada individu yang terlibat dalam suatu organisasi. Tata usaha Fakultas Tarbiyah, memiliki lima orang staf administrasi. Masing-masing telah diberikan tupoksinya dan bekerja sesuai dengan tupoksinya tersebut. yakni:

Kepala bagian tata usaha Fakultas Tarbiyah ${ }^{13}$, menyatakan dalam wawancara,

Staf administrasi telah mempunyai tugas masing-masing. Dan dituntut untuk bekerja sesuai dengan tupoksinya tersebut. Olehnya itu untuk penyelenggara informasi dilakukan oleh Maulana Akbar yang memang ditugaskan sebagai penyelenggara publikasi informasi.

Staf administrasi, ${ }^{14}$ pun menuturkan bahwa:

Secara teknis, penyebaran informasi adalah tugas kami sebagai staf administrasi, namun karena ada inisiatif dari kabag tata usaha FATIK, untuk menggunakan media sosial facebook dalam hal publikasi, jadi setiap informasi terutama yang berkaitan dengan akademik dan kemahasiswaan, itu setelah kami buat, selanjutnya diteruskan ke kabag tata usaha FATIK untuk segera dipublikasikan. Mengingat pula melalui penggunaan media facebook itu, maka informasinya lebih cepat diperoleh mahasiswa.

${ }^{12}$ Edwin B. Flippo, Personel Management (Manajemen Personalia), Edisi VII Jilid II, Terjemahan Alponso S, (Jakarta: Erlangga, 2002), hlm. 5-7.

${ }^{13}$ Amari, Wawancara, 5 Maret 2018.

${ }^{14}$ Maulana Akbar, Wawancara, 5 Maret 2018. 
Staf administrasi di Fakultas Tarbiyah, yakni Ratnasari Baharudin, SE, sebagai kepala sub bagian AUK dan Bendahara Fakultas Tarbiyah. Dra. St. Rukayyah sebagai kepala sub bagian AKMA, yang bertugas melayani mahasiswa dalam pengambilan ijazah, legalisir ijazah, dan lain sebagainya yang berhubungan dengan alumni. Supriyono K, S. Si, sebagai staf yang bertugas melayani mahasiswa dalam pembuatan kartu mahasiswa, surat menyurat mahasiswa, seperti surat penelitian, surat cuti, serta segala yang berkaitan dengan proses penawaran mahasiswa. Sedangkan Maulana Akbar, sebagai staf administrasi yang bertugas sebagai penyelenggara publikasi informasi. Jadi, segala informasi baik akademik dan kemahasiswaan, selalu dipublikasikan oleh Maulana Akbar. Namun, Kabag tata usaha FATIK, Amari, S. Ag, M. AP turut andil dalam penyebaran informasi akademik dan kemahasiswaan melalui media sosial facebook.

Hasil wawancara dengan Amari, selaku kabag tata usaha Fakultas Tarbiyah, menyatakan bahwa publikasi informasi sejak 2017 lebih dominan menggunakan media sosial facebook. Namun, publikasi melalui media cetak yakni, papan penguumuman masih tetap digunakan sebagai bukti pendukung telah dilakukannya publikasi informasi.

c) Pelaksanaan Publikasi Informasi

Dalam pelaksanaan publikasi informasi, pihak humas (hubungan masyarakat) atau yang menyampaikan informasi, harus memperhatikan beberapa hal. Misalnya penggunaan media publikasi informasi. Fakultas Tarbiyah dan Ilmu Keguruan IAIN Kendari, menggunakan salah satu media sosial facebook dalam mempublikasikan informasi, dimana penggunaan media ini dianggap dapat memudahkan mahasiswa dalam memperoleh informasi tersebut. Hal ini merupakan inisiatif dari kepala bagian tata usaha FATIK IAIN Kendari. Dalam wawancara kabag tata usaha Fakultas Tarbiyah (Amari), menuturkan bahwa:

Salah satu model publikasi informasi yang kami terapkan di FATIK yakni, menggunakan media sosial facebook. Model ini merupakan salah satu model yang efektif bagi kami untuk mempublikasikan informasi karena mengingat jumlah mahasiswa Fakultas Tarbiyah dan Ilmu Keguruan itu lumayan sangat banyak dibandingkan fakultas yang lainnya di IAIN Kendari, olehnya itu supaya setiap informasi yang berkaitan dengan akademik dan kemahasiswaan sampai kepada mahasiswa maka media sosial facebook menjadi salah satu strategi kami dalam penyebaran informasi.

Mahasiswa Tadris matematika, ${ }^{15}$ pun menambahkan argumennya:

Facebook bukanlah hal baru dikalangan mahasiswa. Mahasiswa sudah terbiasa membaca informasi atau berita dari facebook sehingga dengan adanya akun

${ }^{15}$ Hanisa, Wawancara, 8 Maret 2018. 
Facebook FATIK ini menjadikan mahasiswa lebih mudah memperoleh informasi dan sering men-search informasi di akun facebook Tata Usaha Fatik dan mahasiswa pun akan mendapatkan informasi tersebut.

Kabag tata usaha FATIK menambahkan argumennya juga bahwa faktor penggunakan media sosial facebook ini, disebabkan empat faktor, yakni banyaknya mahasiswa yang konsultasi, website fakultas kurang efektif, menghindari pertanyaan yang berulang-ulang, serta model publikasi media cetak kurang efektif. Keempat faktor di atas, menyebabkan kepala bagian akademik Fakultas Tarbiyah mengimplementasikan sistem publikasi informasi melalui media sosial facebook. Namun publikasi informasi melalui media cetak pun masih tetap digunakan. Hasil wawancara dengan kabag tata usaha juga staf administrasi, memaparkan pula bahwa pihak yang menyebarkan informasi, yakni staf administrasi dan juga dilakukan oleh kepala bagian tata usaha FATIK IAIN Kendari. Selain itu, pelaksana dari publikasi ini yakni staf administrasi, Maulana Akbar melalui media cetak. Dan kabag tata usaha Fakultas Tarbiyah dan ilmu keguruan IAIN Kendari, melalui media sosial.

\section{d) Pengawasan Publikasi Informasi}

Pengawasan adalah proses mengamati, memeriksa, mengendalikan, dan mengkoreksi pelaksaan seluruh kegiatan organisasi agar semua pekerjaan berjalan sesuai dengan rencana yang telah ditetapkan sebelumnya. Pengawasan dan perencanaan seperti dua sisi dari mata uang yang sama. Pengawasan tidak mungkin dijalankan tanpa perencanaan yang jelas. ${ }^{16}$ Kegiatan pengawasan dapat dilakukan dengan melakukan pengamatan, evaluasi dan meminta laporan terkait publikasi informasi. Hasil wawancara dengan Staf administrasi tata usaha ${ }^{17}$, memaparkan bahwa:

Tugas kami adalah mempublikasikan informasi, terutama melalui media cetak. Jadi dalam melakukan publikasi itu, selalu ada pengawasan dan pengamatan dari kabag tata usaha FATIK IAIN Kendari itu sendiri. Terutama terkait mahasiswa dalam hal memperoleh informasi. Dan sebelum dilakukan publikasi informasi kepada mahasiswa, telah ada kordinasi awal dengan kabag tata usaha FATIK sehingga Informasi tersebut pun memudahkan kabag FATIK dalam melakukan pengawasan.

Jadi berdasarkan hasil wawancara dengan staf administrasi di atas, dapat disimpulkan bahwa publikasi informasi di fakulas tarbiyah dan ilmu keguruan IAIN Kendari tidak terlepas dari pengawasan kabag TU FATIK itu sendiri. Hal ini dilakukan agar publikasi informasi betul-betul terdistribusi kepada mahasiswa yang merupakan salah satu kebutuhan mereka pula. Kepala bagian tata usaha FATIK IAIN Kendari, menuturkan sebagai berikut:

\footnotetext{
${ }^{16}$ Muhammad Faula Azmie, "Manajemen Pengelolaan Portal Berita Www.Goriau.Com Dalam Menarik Minat Baca Pada Media Sosial”, Jom FISIP, Vol. 2 No. 1 (Februari 2015): 1-16.

${ }^{17}$ Maulana Akbar, Wawancara, Maret 2018.
} 
Informasi yang telah dipublikasikan itu tidak terhenti setelah penyelenggaraannya. Namun, tahap paling pentingnya adalah mengamati respon dari informasi itu. Terutama respon dari pihak mahasiswa. Hal ini untuk mengetahui bahwa informasi itu telah diperhatikan oleh peneriman informasi. Juga kegiatan pengawasan ini bertujuan untuk mengelolah berbagai tanggapan yang nantinya akan muncul. Sehingga kami yang menyebarkan informasi pula bisa memberikan respon balik mengenai tanggapan dari informasi yang telah kami publikasikan tersebut.

Hasil pemaparan informan di atas, dapat disimpulkan bahwa pengawasan dari publikasi informasi itu dilakukan oleh kabag tata usaha Fakultas Tarbiyah juga pimpinan Fakultas Tarbiyah. Sebagaimana hasil observasi penulis juga melihat bahwa setiap informasi yang dipublikasikan terutama melalui media sosial facebook itu selalu ditanggapi oleh admin facebook itu dan terkadang pula adanya tanggapan dari pimpinan Fakultas Tarbiyah. Hal ini menandakan bahwa setelah adanya publikasi informasi, maka pihak yang menyelenggarakan informasi tersebut selalu melakukan pengawasan terhadap informasi yang telah dipublikasikan tersebut.

Jadi berdasarkan pernyataan informan dan hasil observasi penulis, maka dapat ditarik sebuah kesimpulan bahwa dalam melakukan publikasi informasi, pihak public relations (penyebar informasi) menerapkan fungsi manajemen dalam implementasinya. Sehingga segala informasi yang berkaitan dengan akademik dan kemahasiswaan dengan mudah diketahui oleh mahasiswa Fakultas Tarbiyah dan ilmu keguruan IAIN Kendari.

Manajemen publikasi informasi Fakultas Tarbiyah dan Ilmu Keguruan dalam menyelenggarakan publikasi informasi, diawali dengan tahap perencanaan, pengorganisasian, pelaksanaan, dan pengawasan. Hal ini dibuktikan dengan adanya penyebaran informasi yang tersistematis dan mudah diperoleh bagi kalangan mahaiswa. Adapun perencanaan dari publikasi informasi, meliputi analisis informasi yang akan dipublikasikan, yakni informasi akademik, kemahasiswaan atau umum. pihak-pihak terkait yang terlibat dalam publikasi, yaitu pimpinan fakultas tarbiyah, masing-masing ketua prodi, dan kabag tata usaha serta staf administrasi fakultas tarbiyah. Serta media publikasi yang akan digunakan, ada dua media sosial facebook dan media cetak. Tahap pengorganisasian, yakni Tata usaha fakultas tarbiyah, memiliki lima orang staf administrasi. Masing-masing telah diberikan tupoksinya, yakni Ratnasari Baharudin, SE, sebagai kepala sub bagian AUAK atau sebagai Bendahara fakultas tarbiyah. Dra. St. Rukayyah sebagai kepala sub bagian AKMA, yang bertugas melayani mahasiswa dalam rangka seperti pengambilan ijazah, legalisir ijazah, dan lain sebagainya yang berhubungan dengan alumni. Supriyono K, S. Si, sebagai staf yang bertugas sebagai melayani mahasiswa dalam pembuatan kartu mahasiswa, surat menyurat mahasiswa, seperti surat penelitian, surat cuti, serta segala yang berkaitan dengan proses penawaran mahasiswa. Sedangkan Maulana Akbar, sebagai staf administrasi yang bertugas sebagai penyelenggara publikasi informasi. Namun, dalam publikasi informasi melalui media sosial facebook, maka kabag tata usaha FATIK, 
turut andil dalam penyebaran informasi akademik dan kemahasiswaan tersebut. Tahap Pelaksanaan publikasi informasi ini, dilakukan oleh staf administrasi fakultas tarbiyah, juga kepala bagian tata usaha fakultas tarbiyah melalui penggunaaan media cetak dan media sosial facebook. Tahap terakhir yakni pengawasan dari publikasi informasi tersebut, sejatinya merupakan tugas dari kabag tata usaha FATIK IAIN Kendari, namun oleh pimpinan fakultas tarbiyah pula ikut terlibat dalam pengawasan publikasi informasi tersebut. Peran Kabag dan staf administrasi dalam hal ini berfungsi sebagai Humas yang memiliki peran penting dalam penyebaran informasi lewat media social facebook kepada para mahasiswa. Perguruan tinggi banyak menggunakan media social seperti facebook dalam mensosialisasikan berbagai kegiatan akdemik, seperti halnya yang juga dilakukan di Universitas Sultan Ageng Tirtayasa, juga Universitas Abdurrab Pekanbaru dimana pihak humas membuat media publikasi untuk mensosialisasikan kepada seluruh civitas akademika kampus ini, baik melalui media website kampus ${ }^{18}$. Grunig dan Hunt yang menyatakan bahwa Humas merupakan bagian penting dalam organisasi yang menjembatani tindakan komunikasi antara organisasi dengan publik ${ }^{19}$ Peran ini sangat krusial, sehingga dalam menyelenggarakan publikasi informasi dibutuhkan adanya penerapan manajemen yang baik.

Temuan-temuan penelitian diatas sebagaimana yang ditemukan pula oleh Muhammad Faula Azmie dalam penelitianya di Portal Berita Www.Goriau.Com bahwa fungsi manajemen yang diterapkan redaksi GoRiau.com dalam pengelolaan berita online dimulai dari perencanaan (planning), pengorganisasian (organizing), penggerakan (actuating), dan pengawasan (controlling) yang memungkinkan terjadinya interaksi secara langsung ole pembaca dengan portal berita di media sosial. ${ }^{20}$

\section{Peranan Media Sosial Facebook dalam Manajemen Publikasi Informasi Fakultas Tarbiyah Dan Ilmu Keguruan IAIN Kendari}

Dalam manajemen publikasi arus informasi menjadi hal yang sangat penting. Pusat perhatian dari komunikasi dalam manajemen publikasi adalah kecanggihan dalam mengolah dan menyebarluaskan informasi. Oleh sebab itu, yang menjadi central point disini adalah persoalan informasi yang diolah dan disebarluaskan ${ }^{21}$. Informasi inilah yang sesungguhnya dikomunikasikan ke segenap publik dari organisasi yang bersangkutan.Informasi inilah yang sesungguhnya dikomunikasikan ke segenap publik dari organisasi yang bersangkutan.Adapun peranan media sosial facebook dalam manajemen publikasi informasi Fakultas Tarbiyah dan ilmu keguruan IAIN Kendari,

18 Nesyiatul Eisyiah dan Deviani Setyorini, "Strategi Humas Universitas Sultan Ageng Tirtayasa", portalgaruda.org. Diakses 10 Oktober 2018; Lihat pula Nadyatul Khairina, "Implementasi Public Relations Dalam Membangun Citra Positif Universitas Abdurrab Pekanbaru”, JOM FISIP Vol. 4 No. 2 (Oktober 2017).

19 J.E. Grunig \& Hunt, T. (1984). Managing Public Relations, (New York: Holt, Rinehart \& Winston)

${ }^{20}$ Muhammad Faula Azmie, "Manajemen Pengelolaan...

${ }^{21}$ Aswad Ishak, "Peran Public Relations dalam Komunikasi Organisasi”, Jurnal Komunikasi, Vol. 1, No. 4, (Januari 2012): 373-380. 
terbagi menjadi tiga bagian, yaitu optimalisasi informasi, kemudahan publikasi dan akses informasi serta memiliki fitur menarik dalam publikasi informasi. Adapun pemaparan dari peranan media sosial tersebut, yakni:

\section{a. Optimalisasi}

Akun facebook tata usaha Fakultas Tarbiyah, telah menjalin pertemanan dengan pengguna facebook sebanyak 4646 akun, terdiri dari mahasiswa IAIN Kendari, tanpa terkecuali mahasiswa dari fakultas lain, tenaga pendidik dan kependidikan, alumni, serta pemerhati IAIN Kendari. ${ }^{22}$

Adapun Informasi yang dipublikasikan di Fakultas Tarbiyah itu terbagi menjadi tiga macam yakni, informasi akademik, kemahasiswaan dan informasi umum. Kepala bagian tata usaha Fakultas Tarbiyah dan ilmu keguruan IAIN Kendari ${ }^{23}$, memaparkan bahwa:

Akun facebook yang telah dijadikan sebagai sarana publikasi informasi, telah mengoptimalkan informasi yang kami publikasikan kepada mahasiswa. Hal ini berbeda dengan media yang kami gunakan terdahulu, yakni media cetak yang terkadang informasi yang dipublikasikan itu tidak sampai kepada mahasiswa. Olehnya itu eksistensi dari akun facebook ini senantiasa terus digunakan sebagai media publikasi informasi."

Peranan media sosial ini pula dirasakan oleh staf administrasi Fakultas Tarbiyah. ${ }^{24}$ Seperti yang diungkapkan oleh salah seorang staf berikut:

Media sosial facebook yang digunakan di fakultas, memiliki dampak positif bagi kami dalam hal penyebaran informasi. Terutama dalam hal tanggapan dari informasi. Mahasiswa sudah jarang mendatangi staf untuk berkonsultasi terkait dengan kegiatan akdemik, namun secara langsung ditangani oleh Kabag tata usaha fakultas selaku admin akun facebook.

Berdasarkan pemaparan para informan diatas dapat disimpulkan bahwa publikasi informasi di Fakultas Tarbiyah menjadi lebih optimal dengan penggunaan media sosial facebook. Jadi, melalui penggunaan media sosial facebook, publikasi informasi di Fakultas Tarbiyah menjadi lebih optimal dan efektif. Penggunaan facebook manjadi media paling efektif dalam menyampaikan pesan. Pengguna dalam hal ini adalah mahasiswa akan berupaya masuk pada komunitas tertentu karena memiliki keterkaitan dengan produk informasi yang ditawarkan ${ }^{25}$, sehingga media ini menjadi tepat dipilih sebagai media asasran informasi.

\footnotetext{
${ }^{22}$ Sumber https://web.facebook.com/tu.fatik?ref=br rs

${ }^{23}$ Amari, Wawancara, 5 Maret 2018.

${ }^{24}$ Supriyono K, Wawancara, 6 Maret 2018

${ }^{25}$ Bambang Supradono, Ayu Noviani Hanum, "Peran Sosial Media Untuk Manajemen Hubungan Dengan Pelanggan Pada Layanan E-Commerce", Jurnal VALUE ADDED, Vol. 7, No.2, (Maret 2011 - Agustus 2011): 33-45 http://jurnal.unimus.ac.id. Diakses tanggal 10 Oktober 2018.
} 


\section{b. Kemudahan}

Penggunaan media social seperti halnya facebook memiliki banyak tujuan. Tujuan-tujuan tersebut diantaranya adalah kesenangan, komunikasi, informasi, dan transaksi ${ }^{26}$. Situs jejaring sosial digunakan oleh banyak orang dengan berbagai tujuan. Sopiah (Sopiah, 2013) membagi tujuan tersebut Sejak digunakannya media sosial facebook sebagai sarana publikasi infomasi. memiliki dampak yang sangat besar baik dari segi publisitas, maupun stakeholder (mahasiswa dan staf administrasi Fakultas Tarbiyah). Kepala bagian tata usaha FATIK IAIN Kendari, ${ }^{27}$ selaku admin/pengelolah akun facebookmengungkapkan bahwa:

"Media sosial facebook ini sangat mempermudah kami dalam penyebaran informasi. Biasanya jika pihak JFU Menyampaikan informasi lewat papan informasi, tidak semua mahasiswa mengetahuinya. Akan tetapi, dengan adanya akun facebook, maka setiap informasi yang kami publikasikan tersebut cepat tersebar kepada mahasiswa yang lain dengan cara membagikan informasi tersebut melalui akunnya masing-masing. Selain itu juga informasi yang disampaikan itu selalu direspon oleh mahasiswa baik hanya sekedar menyukai informasi itu atau meninggalkan komentar dari informasi yang dipublikasikan tersebut."

Mahasiswa mengungkapkan bahwa informasi akademik itu sangat penting untuk diperoleh tepat waktu dan tidak terbatas. Sehingga media publikasi dari informasi tersebut menunjang pula dalam hal memperolehnya. Seperti yang diungkapkan oleh mahasiswa Prodi PAI, ${ }^{28}$ berikut:

Media sosial facebook TU FATIK sangat memudahkan/membantu dalam penyebaran infomasi akedemik dan kemahasiswaan. Media publikasi ini, menjadikan informasi yang dipublikasikan itu bisa diperoleh dengan cepat dibandingkan dengan mencari informasi di papan pengumuman.

MahasiswaTadris matematika, ${ }^{29}$ pun menambahkan argumennya:

Facebook bukanlah hal baru dikalangan mahasiswa. Mahasiswa sudah terbiasa membaca informasi atau berita dari facebook sehingga dengan adanya akun Facebook FATIK ini menjadikan mahasiswa lebih mudah memperoleh informasi dan sering men-search informasi di akun facebook Tata Usaha Fatik dan mahasiswa pun akan mendapatkan informasi tersebut.

${ }^{26}$ N Sopiah, "Faktor-Faktor yang Mempengaruhi Penggunaan Media Facebook". Proceeding Seminar Nasional Aplikasi Teknologi Informasi (SNATI) 2013 (pp. 16-20). Universitas Islam Indonesia, 2013.

${ }^{27}$ Amari, wawancara 5 Maret 2018.

${ }^{28}$ Anisa Dea Endarwati, Wawancara, 2 Maret 2018

${ }^{29}$ Hanisa, Wawancara 5 Maret 2018 
Informan lain $^{30}$ pun merasakan peranan media sosial facebook ini dalam manajemen publikasi informasi. Sebagaimana hasil wawancaranya berikut ini:

Sebelum digunakannya media sosial facebook, biasanya mahasiswa sedikit kesulitan dalam memperoleh informasi. Karena harus ke kampus terlebih dahulu, kemudian mencari-cari informasi di papan pengumuman. Berbeda dengan sekarang, dimana pun dan kapan pun kita bisa mengakses informasi kegiatan akademik dan kemahasiswaan fakultas selama masih online di media sosial facebook.

Berdasarkan hasil wawancara dengan informan diatas, dapat disimpulkan bahwa dalam hal publisitas, akun facebook tata usaha fakultas memberikan kontribusi bagi staf administrasi dengan mudah mempublikasikan informasi. Sedangkan bagi mahasiswa, media sosial tersebut menunjang dalam hal memperoleh informsi dengan mudah, akurat, relevan dan cepat. Sebagaimana dikemukakan Cheung et al bahwa salah satu alasan utama seseorang menggunakan situs jejaring sosial adalah untuk berkomunikasi dan terkoneksi secara instan dengan orang lain. ${ }^{31}$ (Cheung et al., 2011). Olehnya itu media sosial facebook yang diimplementasikan di Fakultas Tarbiyah sangat memudahkan berbagai pihak dalam mendapatkan informasi.

\section{c. Memiliki Fitur-Fitur Menarik}

Media sosial memiliki karakterisitik yang beragam misalnya, memiliki fitur-fitur menarik, seperti tampilan multimedia dan lain sebagainya. Media social facebook misalnya sangat familiar bagi mahasiswa, sehingga dapat dimanfaatkan untuk mendekatkan diri dan menjalin komunikasi dengan mahasiswa ${ }^{32}$. Dalam menyebarkan informasi, kepala bagian tata usaha fakultas selaku pengelolah akun facebook, biasanya memanfatkan media gambar/foto yang singkron dengan informasi yang dipublikasikan. Sehingga pengguna media sosial (terkhususnya mahasiswa) dengan cepat menangkap maksud dari informasi yang dipublikasikan tersebut. Hasil wawancara bersama kabag tata usaha Fakultas Tarbiyah, ${ }^{33}$ yakni:

Publikasi informasi melalui media facebook ini, lebih menarik dibandingkan media cetak. Hal ini karena dalam melakukan penyebaran informasi, maka bisa disertai dengan fitur-fitur menarik, seperti gambar atau video yang disingkronkan dengan informasi yang akan dipublikasikan tersebut. Sehingga hal ini pula

${ }^{30}$ Lita Wati Buton, Mahasiswa (tadris Matematika), Wawancara, 13 Maret 2018

${ }^{31}$ Cheung, C. M. K., Chiu, P. -Y., \& Lee, M. K. O. Online social networks: Why do students use facebook? Computers in Human Behavior, 27, 1337-1343. http://doi. org/10. 1016/j. chb. 2010. 07. 028, 2011.

${ }^{32}$ Almed Hamzah, "Pola Penggunaan Situs Jejaring Sosial Sebagai Media Pembelajaran Untuk Mahasiswa", Jurnal Teknoin Vol. 21 No. 4 (Desember 2015): 167-177.

${ }^{33}$ Amari, Wawancara 5 Maret 2018. 
menjadi salah satu alasan informasi yang dipublikasikan menjadi lebih menarik perhatian para pengguna facebook, terkhususnya mahasiswa Fakultas Tarbiyah.

Informan lain ${ }^{34}$, menambahkan argumennya, berikut:

Publikasi informasi melalui akun facebook itu cenderung lebih cepat penyebarannya dibandingkan media lain. Apalagi informasi yang disampaikan itu disertai dengan gambar kegiatan akademik fakultas. Selain itu pula, yang lebih menguntungkan lagi dari penggunaan media sosial facebook ini, setiap ada kritik dan saran yang kami ajukan terkait dengan informasi yang dipublikasikan maupun kegiatan akademik lainnya, maka admin akun facebook selalu menanggapi komentar maupun saran kami tersebut dengan positif. Bagi saya, peranan media publikasi melalui akun facebook itu sangat berdampak positif.

Olehnya itu, penggunaan media sosial facebook ini, melalui beragam fitur menariknya, bisa membuat informasi yang dipublikasikan tersebut lebih mudah diketahui dibandingkan penggunaan media cetak. Seperti gambar di bawah ini:

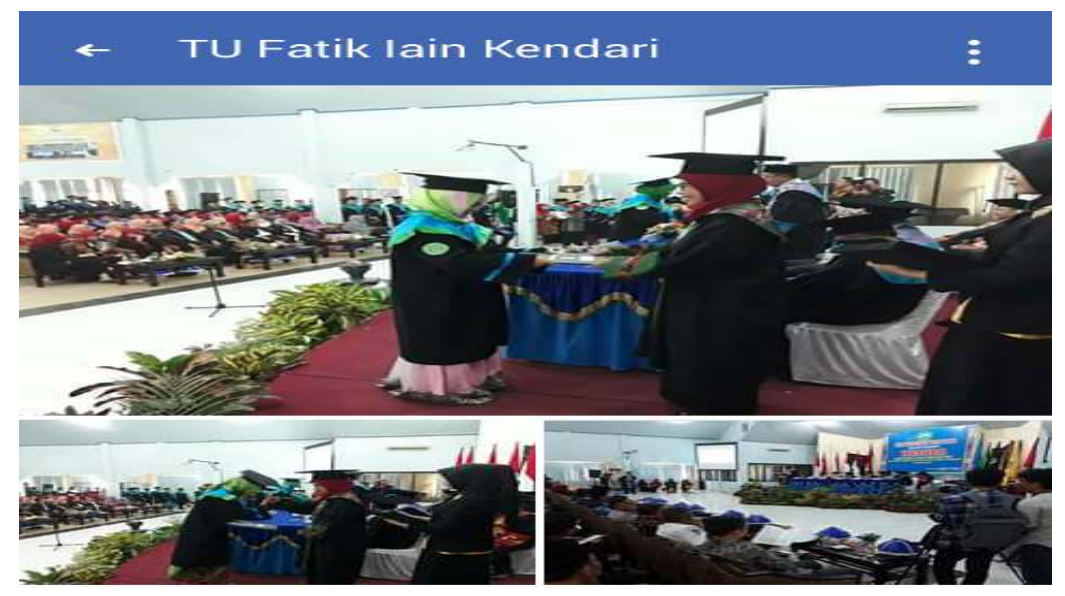

Gambar 1; Informasi wisuda tahun 2018 IAIN Kendari

\footnotetext{
${ }^{34}$ Waode Salmi Rumbira, Mahasiswa (Tadris Fisika), Wawancara, 10 Maret 2018.
} 


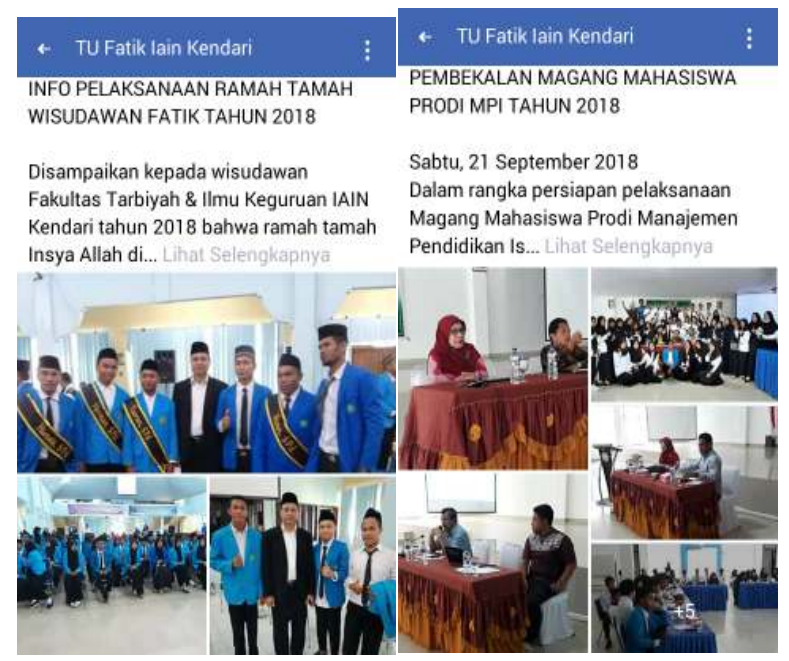

Gambar 2; Kegiatan akademik Fatik IAIN Kendari

Selain alasan mudah diterima, penggunaan fitur menarik ini pula dimaksudkan agar memperkenalkan segala kegiatan yang dilakukan oleh fakultas. Sehingga hal in dapat menarik minat orang yang memperhatikan informasi tersebut. kepala bagian tata usaha fakultas, ${ }^{35}$ menurunkan argumennya:

Penggunaan fitur menarik ini akan lebih mudah pula memperkenalkan segala kegiatan yang dilakukan oleh fakultas tarbiyah sehingga hal ini pula dapat menarik perhatian dan minat penerima informasi.

Berdasarkan pemaparan para informan diatas maka dapat disimpulkan bahwa peranan media sosial facebook dalam manjemen publikasi informasi sangat berdampak positif dan penggunaannya efektif di fakultas tarbiyah dan ilmu keguruan IAIN Kendari.

Media sosial, memilki enam peranan menurut McQuail, yakni sebagai window on event and experience; a mirror of event in society and the world, implying a faithful reflection; sebagai guide/acuan; sebagai publikasi informasi, sebagai filter informasi; dan interlocutor. ${ }^{36}$

Dari keenam peranan media sosial facebook di atas, fokus peranan media sosial facebook yang dibahas adalah publikasi informasi. Adapun peranan media sosial facebook dalam manajemen publikasi informasi Fakultas Tarbiyah dan Ilmu Keguruan IAIN Kendari, yakni untuk optimalisasi informasi, kemudahan publikasi dan akses informasi, serta memiliki fitur-fitur menarik dalam publikasi informasi.

35 Amari, wawancara 5 Maret 2018.

36 Lihat Aria Aditya Setiawan, "Peran Media Masa dalam Meningkatkan Kualitas Kepemerintahan Lokal Berbasis Human Security di Kota Jayapura", Semarang, Universitas Diponegoro ejournal.http://ejournal.undip.ac.id/index.php/politika/article/download/5096/4621. 
Penggunaan media social oleh mahasiswa memang merupakan hal yang lumrah dewasa ini. Terdapat banyak sekali aktivitas yang dilakukan oleh mahasiswa ketika menggunakan situs jejaring social dalam mengakss hal-hal yang terkait dengan pendidikan yang sedang ditempuhnya. Dalam temuan penelitian Shen dan Khalifa menjelaskan bahwa minimal ada sebelas aktivitas yang dilakukan oleh mahasiswa dalam situs jejaring sosial. Dari ke sebelas aktivitas ini yang berhubungan dengan dunia pendidikan adalah mencari informasi, mempelajari proses bekerja sesuatu hal, berbagi informasi dengan teman, menggali ide, dan memecahkan sebuah masalah. ${ }^{37}$ Publikasi informasi di Fakultas Tarbiyah bisa dikatakan telah optimal dengan penggunaan media sosial facebook ini. Menurut Winardi, optimalisasi adalah ukuran yang menyebabkan tercapainya tujuan sedangkan jika dipandang dari sudut usaha, optimalisasi adalah usaha memaksimalkan kegiatan sehingga mewujudkan keuntungan yang diinginkan atau dikehendaki. Dalam KBBI pun, W.J.S.poerdwadarminta mengemukakan bahwa: "Optimalisasi adalah hasil yang dicapai sesuai dengan keinginan, jadi optimalisasi merupakan pencapaian hasil sesuai harapansecara efektif dan efisien". Optimalisasi banyak juga diartikan sebagai ukuran dimana semua kebutuhan dapat dipenuhi dari kegiatan- kegiatan yang dilaksanakan. ${ }^{38}$ Jadi, dengan adanya media sosial facebook sebagai media publikasi di fakultas, menjadikan informasi tersebut lebih efektif dan efisien diakses oleh mahasiswa.

Kemudahan menurut Davis adalah tingkat dimana seseorang meyakini bahwa penggunaan teknologi informasi merupakan hal yang mudah yang tidak memerlukan usaha keras dari pemakainya. ${ }^{39}$ Begitu pula dengan publikasi informasi di Fakultas Tarbiyah, dalam kegunaannyamemudahkan semua stakeholder fakultas tarbiyah, yakni mahasiswa dan staf administrasi.Peran media sosial facebook selanjutnya, yakni dalam mempublikasikan informasi, disertai dengan gambaryang menarik yang bisa membuat informasi yang dipublikasikan tersebut lebih mudah diketahui maknanya dibandingkan penggunaan media cetak. Selain alasan mudah diterima, penggunaan fitur menarik ini pula dimaksudkan agar memperkenalkan segala kegiatan yang dilakukan oleh fakultas, sehingga hal ini dapat menarik minat orang yang memperhatikan informasi tersebut.

\section{Penutup}

Manajemen publikasi informasi Fakultas Tarbiyah dan Ilmu Keguruan dalam menyelenggarakan publikasi informasi, diawali dengan tahap perencanaan, pengorganisasian, pelaksanaan, dan pengawasan. Hal ini dibuktikan dengan adanya

\footnotetext{
${ }^{37}$ Shen, K. N., \& Khalifa, M. "Facebook Usage among Arabic College Students: preliminary findings on gender differences", 2010.

${ }^{38}$ Muhammad AidinAli, "Analisis Optimalisasi PelayananKonsumenBerdasarkan Teori Antrian Pada Kaltimgps.Com Di Samarinda”, Jurnal: Ilmu Administrasi Bisnis, Vol. 3 No. 2 Tahun 2014, h. 348.

${ }^{39}$ Agung Budi Prasetyo, dkk, "Pengaruh Kemudahan Dan Kemanfaatan Website TerhadapKinerja (Survei Pada Karyawan Dinas Komunikasi Dan Informatika Jawa Timur (KOMINFOJATIM)". Jurnal: Administrasi Bisnis (JAB), Vol. 8 No. 1 (Februari 2014), h. 3.
} 
penyebaran informasi yang tersistematis dan mudah diperoleh bagi kalangan mahaiswa.

Adapun perencanaan dari publikasi informasi, meliputi analisis informasi yang akan dipublikasikan, yakni informasi akademik, kemahasiswaan atau umum. pihakpihak terkait yang terlibat dalam publikasi, yaitu pimpinan Fakultas Tarbiyah, masingmasing ketua prodi, dan kabag tata usaha serta staf administrasi Fakultas Tarbiyah. Serta media publikasi yang akan digunakan, ada dua media sosial facebook dan media cetak. Tahap pengorganisasian, yakni Tata usaha Fakultas Tarbiyah, memiliki lima orang staf administrasi. Masing-masing telah diberikan tupoksinya, yakni Ratnasari Baharudin, SE, sebagai kepala sub bagian AUAK atau sebagai Bendahara Fakultas Tarbiyah. Dra. St. Rukayyah sebagai kepala sub bagian AKMA, yang bertugas melayani mahasiswa dalam rangka seperti pengambilan ijazah, legalisir ijazah, dan lain sebagainya yang berhubungan dengan alumni. Supriyono K, S. Si, sebagai staf yang bertugas melayani mahasiswa dalam pembuatan kartu mahasiswa, surat-menyurat mahasiswa, seperti surat penelitian, surat cuti, serta segala yang berkaitan dengan proses penawaran mahasiswa. Sedangkan Maulana Akbar, sebagai staf administrasi yang bertugas sebagai penyelenggara publikasi informasi akademik dan kemahasiswaan Fakultas Tarbiyah dan Ilmu Keguruan. Namun, kepala bagian tata usaha FATIK, Amari, S.Ag, M.AP juga turut andil dalam publikasi informasi melalui media sosial facebook. Tahap Pelaksanaan publikasi informasi ini, dilakukan oleh staf administrasi Fakultas Tarbiyah, juga kepala bagian tata usaha Fakultas Tarbiyah melalui penggunaaan media cetak dan media sosial facebook. Tahap terakhir yakni pengawasan dari publikasi informasi tersebut, sejatinya merupakan tugas dari kabag tata usaha FATIK IAIN Kendari, namun oleh pimpinan Fakultas Tarbiyah pula ikut terlibat dalam pengawasan publikasi informasi tersebut. (2) Adapun peranan media sosial facebook dalam manajemen publikasi informasi Fakultas Tarbiyah dan ilmu keguruan IAIN Kendari, ada tiga, yakni optimalisasi informasi, kemudahan publikasi dan perolehan informasi, serta memiliki fitur-fitur menarik dalam publikasi informasi.

\section{Daftar Pustaka}

Ali, Muhammad Aidi. "Analisis Optimalisasi Pelayanan Konsumen Berdasarkan Teori Antrian Pada Kaltimgps.Com Di Samarinda". Jurnal: Ilmu Administrasi Bisnis, Vol. 3 No. 2 Tahun 2014.

Asmaya, Fela. "Pengaruh Penggunaan Media Sosial Facebook Terhadap Perilaku Prososial Remaja Di Kenagarian Kota Bangun”. Jurnal Jom FISIP, Vol. 2 No. 2 (Oktober 2015).

Azmie, Muhammad Faula "Manajemen Pengelolaan Portal Berita Www.Goriau.Com Dalam Menarik Minat Baca Pada Media Sosial", Jom FISIP, Vol. 2 No. 1 (Februari 2015): 1-16. 
Basri, Hasan Basri. "Peran Media Sosial Twitter Dalam Interaksi Sosial Pelajar Sekolah Menengah Pertama Di Kota Pekanbaru (Studi Kasus Pelajar Smpn 1 Kota Pekanbaru)". Jom FISIP, Vol. 4 No. 2 (Oktober 2017): 1-15

Cheung, C. M. K., Chiu, P. -Y., \& Lee, M. K. O. Online social networks: Why do students use facebook? Computers in Human Behavior, 27, 1337-1343. http://doi. org/10. 1016/j. chb. 2010. 07. 028, 2011.

Fachrian, Ita dan LM. Tajidun. "Implementasi SMS GATEWAY Dan PAPAN Pengumuman Digital Penyebaran Informasi Kegiatan Akademik (Studi Kasus: Jurusan Teknik Informatika Universitas Halu Oleo)". Jurnal semanTIK, Vol. 11, No. 2 (Juli-Des 2015).

Flippo, Edwin B. Personel Management (Manajemen Personalia). Edisi VII Jilid II, Terjemahan Alponso S. Jakarta: Erlangga, 2002.

Hanafi, Muhammad. "Pengaruh Penggunaan Media Sosial Faceboook Terhadap Motivasi Belajar. Siswa FISIP Universitas Riau". Jurnal: JOM FISIP, Vol. 3 No. 2 (Oktober 2016).

Hamzah, Almed "Pola Penggunaan Situs Jejaring Sosial Sebagai Media Pembelajaran Untuk Mahasiswa”, Jurnal Teknoin Vol. 21 No. 4 (Desember 2015): 167-177.

Hamzah, Yeni Imaniar. "Potensi Media Sosial Sebagai Sarana Promosi Interaktif Bagi Pariwisata Indonesia”. Jurnal JKL, Vol. 8 No. 3 Tahun 2013.

Ishak, Aswad. "Peran Public Relations dalam Komunikasi Organisasi". Jurnal Komunikasi, Vol. 1, No. 4, (Januari 2012): 373-380.

J.E. Grunig \& Hunt, T. (1984). Managing Public Relations. New York: Holt, Rinehart \& Winston

Khairina, Nadyatul. "Implementasi Public Relations Dalam Membangun Citra Positif Universitas Abdurrab Pekanbaru”, JOM FISIP Vol. 4 No. 2 (Oktober 2017).

Purwandari, Emma Octavia. "Perbedaan Fungsi-Fungsi Public Relations dalam Sosialisasi Pemilihan Kepala Daerah (Pilkada) "Kasus di KPUD Yogyakarta dan KPUD Bantul”. Jurnal Ilmu Komunikasi, Vol. 6 No. 2 (Desember 2009).

Prasetyo, Agung Budi dkk. "Pengaruh Kemudahan Dan Kemanfaatan Website Terhadap Kinerja (Survei Pada Karyawan Dinas Komunikasi Dan Informatika Jawa Timur (KOMINFO JATIM)". Jurnal Administrasi Bisnis (JAB), Vol. 8 No. 1 (Februari 2014) 
Rahardja, Untung Khanna Tiara, Lia Suci Wulandari, "Penerapan Web Alumni Sebagai Penunjang Media Informasi Pada Perguruan Tinggi Raharja”, Makalah pada Seminar Nasional Teknologi Informasi dan Multimedia 2016 STMIK AMIKOM Yogyakarta, 6-7 Februari 2016.

Shen, K. N., \& Khalifa, M. "Facebook Usage among Arabic College Students: preliminary findings on gender differences", 2010.

Sopiah, N. "Faktor-Faktor yang Mempengaruhi Penggunaan Media Facebook". Proceeding Seminar Nasional Aplikasi Teknologi Informasi (SNATI) 2013 (pp. 16-20). Universitas Islam Indonesia, 2013.

Triyono, Agus. "Pengaruh Situs Jejaring Sosial Facebook Sebagai Media Alternatif Untuk Promosi”. Jurnal Dian Vol. 11 No. 1 (Januari 2011).

Widayanti, Riya. "Pemanfaatan Media Sosial Untuk Penyebaran Informasi Kegiatan Sekolah Menengah Kejuruan Pasundan Tangerang”. Jurnal Abdimas, Vol. 1 No. 2 (Maret 2015).

Ziveria, Mira. "Pemanfaatan Media Sosial Facebook Sebagai Sarana Efektif Pendukung Kegiatan Perkuliahan di Program Studi Sistem Informasi Institut Teknologi dan Bisnis Kalbe". Jurnal Sains dan Teknologi, Vol. 4 No. 2 (Agustus 2017).

\section{Website}

Duggan, M Ellison M, N. B., Lampe, C., Lenhart, A., \& Madden, M. Social Media Site Usage 2014. http://www. pewinternet. org/2015/01/09/socialmediaupdate-2014/, 2015 Diunduh 18 Agustus 2017.

Eisyiah, Nesyiatul dan Deviani Setyorini, "Strategi Humas Universitas Sultan Ageng Tirtayasa", portalgaruda.org. Diakses $10 \quad$ Oktober 2018https://web.facebook.com/tu.fatik?ref=br_rs

https://tekno.kompas.com/read/2018/03/02/08181617/indonesia-pengguna-facebookterbanyak-ke-4-di-dunia. Diakses tanggal 12 Oktober 2018

https://tech.koropak.co.id/1479/tahun-2018-facebook-masih-mendominasi-mediasosial. Diakses tanggal 12 Oktober 2018

Supradono, Bambang, Ayu Noviani Hanum, "Peran Sosial Media Untuk Manajemen Hubungan Dengan Pelanggan Pada Layanan E-Commerce”, Jurnal VALUE 
Al Izzah: Jurnal Hasil-Hasil Penelitian-ISSN: 1978-9726 (p); 2541-0717 (e) Volume 13, Nomor 2 (November, 2018)

ADDED, Vol. 7, No.2, (Maret 2011 - Agustus 2011): 33-45

http://jurnal.unimus.ac.id. Diakses tanggal 10 Oktober 2018. 